\title{
Effects of stratification depth and dissolved organic matter on brackish bacterioplankton communities
}

\author{
Lorena M. Grubisic ${ }^{1}$, Andreas Brutemark ${ }^{2,5}$, Gesa A. Weyhenmeyer ${ }^{1,3}$, \\ Johan Wikner ${ }^{4}$, Ulf Båmstedt ${ }^{4}$, Stefan Bertilsson ${ }^{1, *}$ \\ ${ }^{1}$ Department of Ecology and Genetics, Limnology, Uppsala University, 75236 Uppsala, Sweden \\ ${ }^{2}$ Marine Science Centre, University of Kalmar, 39182 Kalmar, Sweden \\ ${ }^{3}$ Department of Aquatic Sciences and Assessment, Swedish University of Agricultural Sciences (SLU), 75007 Uppsala, Sweden \\ ${ }^{4}$ Department of Ecology and Environmental Science, Umeå Marine Sciences Centre, Umeå University, 90187 Umeå, Sweden \\ ${ }^{5}$ Present address: ARONIA Coastal Zone Research Team, Novia University of Applied Sciences \& Åbo Akademi University, \\ 10600 Ekenäs, Finland
}

\begin{abstract}
Bacterioplankton growth is often directly or indirectly controlled by external energy subsidies via organic matter inputs or solar radiation. We carried out a mesocosm experiment to assess how bacterioplankton communities responded to elevated levels of dissolved organic matter (DOM) and experimentally controlled stratification depth. The month-long experiment consisted of 25001 mesocosms subjected to 4 experimental manipulations in triplicate: the stratification depth was set to either 1.5 or $3.5 \mathrm{~m}$, with or without experimental addition of ambient levels of chromophoric DOM. DOM addition had a significant effect on bacterial community composition as assessed by terminal restriction fragment length polymorphism of amplified 16S rRNA genes. In contrast, there were no effects of the DOM amendment on bacterial biomass or production. Mixing depth and the coupled effective light climate in the photic zone also had a significant effect on bacterial community composition. Furthermore, shallow mixing depth was associated with enhanced primary production, whereas DOM addition had a negative effect on phytoplankton biomass and productivity. Our results suggest that bacterial community composition is coupled to primary production under the studied coastal nutrient regime, and point to a key role of DOM quality in controlling bacterioplankton communities.
\end{abstract}

KEY WORDS: Bacterial community composition - Dissolved organic matter - Stratification depth . Mesocosm · Brackish · Phytoplankton

\section{INTRODUCTION}

Aquatic bacterial communities are exposed to gradual and more episodic changes in their external environment. In boreal and temperate areas, one episodic disturbance is the annual spring flood. The frequency and intensity of these disturbance events are predicted to increase in a future scenario of warmer winter temperatures and increased precipitation (Räisänen et al. 2004). As a consequence, coastal stratification patterns are expected to change and export of inorganic nutrients and allochthonous dissolved organic matter (DOM) to the coastal waters will be altered (Bergström \& Jansson 2000, Kisand et al. 2002).

DOM is an important source of energy and nutrients for bacterial production in aquatic ecosystems, particularly in systems with low primary production (Sandberg et al. 2004). Although bacterial production is often heavily subsidized by allochthonous DOM, the dominant fraction of this largely humic material is biologically recalcitrant, with only about 14 to $19 \%$ readily available for bacterial use (Søndergaard \& Middelboe 1995). However, the degradation of riverine humic substances may accelerate under estuarine conditions (Kisand et al. 2008), and since the 
inputs of allochthonous material is substantial for many coastal areas, including the Baltic Sea, increased allochthonous inputs might shift the entire system towards net heterotrophy, thereby uncoupling microbial growth from phytoplankton primary production (Kuparinen et al. 1996).

Several studies have shown that both the concentration and quality of DOM can be an important factor shaping bacterial community composition (BCC) (e.g. Kisand et al. 2002, Eiler et al. 2003, Stepanauskas et al. 2003, Haukka et al. 2005). When examining BCC over seasons in 2 lakes, as well as in batch cultures, Kritzberg et al. (2006) found that BCC was highly influenced by the composition and concentration of DOM across lakes and over seasons, with the origin of the DOM, e.g. allochthonous versus autochthonous, as a key factor in this regard. Besides this influence on BCC, allochthonous inputs of DOM might also create dramatic changes in bacterial abundance and activity (Kisand et al. 2002). The strong impact of allochthonous DOM on BCC is also likely to be significant in the northern Baltic Sea, where the food web is likely to be driven mainly by bacterial secondary production sustained by riverine DOM rather than estuarine phototrophic primary production (Sandberg et al. 2004).

DOM also increases the attenuation of solar radiation in the water column. Such DOM-mediated absorption of solar radiation by humic substances will have a negative impact on phytoplankton primary production and essentially limit production to the uppermost portion of the water column (reviewed in Jones 1998). The increased absorption will also influence stratification patterns that, together with irradiance, will determine the effective light climate for autochthonous primary producers in the upper mixed water column and thereby also the release of autochthonous organic compounds associated with photosynthetic activity (Bertilsson \& Jones 2003). Hence, the composition and activity of the heterotrophic bacterial community is also likely to change in response to the overall light climate and associated shifts in the phytoplankton community.

Based on these assumptions we hypothesized that elevated DOM concentrations and variable light climate will significantly alter BCC and the growth of bacterial heterotrophs. To test this hypothesis, we conducted a factorial month-long mesocosm experiment where BCC and bacterial and phytoplankton production were assessed in response to a combination of experimental DOM amendments and manipulations of stratification depth that influenced the prevailing light climate experienced by planktonic organisms in the upper water column.

\section{MATERIALS AND METHODS}

\section{Experimental design}

The mesocosm experiment was conducted at the Umeå Marine Sciences Centre situated on the Bothnian Sea $\left(63^{\circ} 34^{\prime} \mathrm{N}, 19^{\circ} 50^{\prime} \mathrm{E}\right)$ in the northern Baltic Sea. Mesocosms consisted of 12 insulated polyethylene towers filled with $12^{\circ} \mathrm{C}$ brackish surface water from the Öre estuary. This estuary has a volume of $1 \mathrm{~km}^{3}$ and an average depth of $16 \mathrm{~m}$. The median salinity is 4.4, and it receives freshwater inputs mainly from the Öre River, a watershed dominated by coniferous forests and mires. The hydrological turnover time of the estuary is $14 \mathrm{~d}$.

The experimental mesocosms had a depth of $5 \mathrm{~m}$, with an inner diameter of $0.8 \mathrm{~m}$, resulting in a total volume of 25001 for each system. Controlled heating and cooling (Honeywell AB computer control systems) was used to manipulate the desired stratification depth to either 1.5 or $3.5 \mathrm{~m}$ from the surface. To stabilize the stratification, the density of the bottom water was increased by addition of scientific grade marine salt (Coralife) $24 \mathrm{~h}$ prior to addition of the upper surface water. The salt addition raised salinity about 0.8 units (from 4.4 to 5.2) in the bottom waters. Temperature in the bottom waters was kept at $10 \pm$ $0.3^{\circ} \mathrm{C}$, whereas the upper mixed layer was maintained at $18 \pm 0.4^{\circ} \mathrm{C}$. The layer separating the warmer and less saline waters of the mixed upper layer from the cold and saline bottom waters is hereafter referred to as 'pycnocline'.

The 12 mesocosms were divided into 4 experimental groups with 3 replicates each: (1) addition of DOM and pycnocline at $1.5 \mathrm{~m}$ depth, (2) no addition of DOM and pycnocline at $1.5 \mathrm{~m}$ depth, (3) addition of DOM and pycnocline at $3.5 \mathrm{~m}$ depth and (4) no addition of DOM and pycnocline at $3.5 \mathrm{~m}$ depth. The upper water mass was mixed with a simple airlift system with continuous bubbling through a $3 \mathrm{~cm}$ diameter PVC pipe placed at the tank centre and extending from the surface to the desired manipulation depth (1.5 or $3.5 \mathrm{~m}$ ). Each mesocosm tank was irradiated with a $16 \mathrm{~h}$ light:8 h dark cycle by metal halogen lamps (Philips MH/CDM-T 150W/930) with an emission spectra closely resembling that of the natural sunlight, but with negligible emission in the ultraviolet (UV) band (<400 nm). The mean PAR (photosynthetically active radiation) irradiance measured at $1 \mathrm{~m}$ depth in the mesocosms was $145 \mu \mathrm{mol}$ photons $\mathrm{m}^{-2} \mathrm{~s}^{-1}$.

At the start of the experiment and then every third day for the duration of the experiment, inorganic 
nutrients were added to the upper mixed layer of all tanks. From the third day of the experiment onward, mesocosms subjected to Treatments 1 and 3 were amended with DOM along with the nutrient additions described above. Each nutrient addition was proportional to the volume of the upper mixed layer and represented a $0.9 \mu \mathrm{M}$ increase in ammonia, a $5.8 \mu \mathrm{M}$ increase in nitrate and a $0.7 \mu \mathrm{M}$ increase in phosphate, respectively. Analogously, the addition of DOM in Treatments 1 and 3 corresponded to an increase in dissolved organic carbon (DOC) of $0.03 \mathrm{mmol} \mathrm{C} \mathrm{l}^{-1}$ for each addition. This addition was equivalent to $9.2 \%$ of the initial DOC level in the estuarine water. Altogether 8 DOM additions were made during the month-long experiment, corresponding to a total addition of $0.24 \mathrm{mmol} \mathrm{C} \mathrm{^{-1 }}$. The amount of DOM added to mesocosms was based on the estimated riverine inputs of DOM to the Öre estuary (Pettersson et al. 1997). The DOM added consisted of $80 \%$ (C units) commercially available humic acids, with a C-content of $48 \%$ (SigmaAldrich). The remaining $20 \%$ of the DOM addition was yeast extract, with a C-content of 38.7\% (Difco), supplied as a model substance for autochthonously produced organic carbon present in all riverine water. The ratio of humic substances added relative to this labile model for autochthonous DOM is similar to earlier estimates showing that, on average, $19 \%$ of riverine DOM is biologically labile (Søndergaard \& Middelboe 1995).

\section{Sample collection water characteristics}

Samples for chemical and biological analyses were collected every third day using a Ruttner sampler. Due to leakage from one of the temperature controlling systems, data from one tank had to be removed from the study (Tank 1 with DOM addition and $3.5 \mathrm{~m}$ stratification).

After sampling, nutrients with or without DOM and filtered brackish surface water were added to compensate for the 161 withdrawn each time. Salinity, temperature, oxygen and in vivo chlorophyll a (chl a) were measured every third day using an in situ probe (AADI SeaGuard, Aanderaa Data Instruments). Temperature was continuously logged by a computercontrolled logging system (Honeywell AB) featuring temperature sensors at 3 depths. Extinction curves for PAR were obtained using a Licor LI1400 radiometer with a LI-193 spherical sensor (LI-COR ${ }^{\circledR}$ Inc. Biosciences). Measurements were carried out above the water surface (air), and PAR was then monitored every $0.2 \mathrm{~m}$ from 0 to $2 \mathrm{~m}$ depth. Further down (2 to $5 \mathrm{~m})$, sampling was carried out at $1 \mathrm{~m}$ intervals.

All chemical water analyses followed standard operating procedures of the accredited laboratory at Umeå Marine Sciences Centre. These are based on international standards of the Swedish Standards Institute, the Helsinki Commission COMBINE manual and original scientific papers as described below. Chl a concentration was measured after ethanol extraction of pigments from cells collected on a Whatman GF/C filters and quantified by their fluorescence on a Perkin Elmer LS 30 luminescence spectrometer (Aminot \& Rey 2002, HELCOM 2003). Extended measurement uncertainty, corresponding to a $95 \%$ confidence interval including systematic error, is $\pm 22 \%$.

The GF/C filtrate was analyzed for humic substances by fluorescence spectroscopy at 350/450 nm excitation/emission wavelength according to HELCOM standards (Coble et al. 1990, Wedborg et al. 1994). Primary production was analyzed by incubation of $3.2 \mu \mathrm{Ci}{ }^{14} \mathrm{C}$ bicarbonate (10:30 to $13: 30$ ) at mid-depth of the mixed layer, i.e. at $0.75 \mathrm{~m}$ (Tanks 1 and 2) and $1.75 \mathrm{~m}$ (Tanks 3 and 4), respectively. After incubation, $5 \mathrm{ml}$ subsamples were withdrawn and transferred to scintillation vials, followed by addition of $0.3 \mathrm{ml} 5 \mathrm{M} \mathrm{HCl}$, sparging with air for at least $30 \mathrm{~min}$, addition of $15 \mathrm{ml}$ Optiphase HiSafe 3 scintillation cocktail and mixing for $10 \mathrm{~s}$ before counting on a Beckman scintillation counter. Primary production was calculated as previously described (Colijn \& Edler 1998).

Dissolved ammonium, nitrite, nitrate, phosphate and silicate were analyzed using a 4-channel autoanalyzer (QuAAtro marine, Bran \& Luebbe ${ }^{\circledR}$ ) according to the Swedish standards Institute and HELCOM (Grasshoff et al. 1983). Extended measurement uncertainty varies between 8.4 and $22 \%$ depending on substance. For particulate organic carbon (POC) and nitrogen (PON), 100 to $200 \mathrm{ml}$ water was filtered onto duplicate precombusted GF/F glassfibre filters, which were dried for $2 \mathrm{~h}$ at $450^{\circ} \mathrm{C}$, and then analyzed with a Carlo Erba elemental analyzer. Samples for analyses of bacterial abundance, biomass and morphology were collected at 10 occasions and analyzed by epifluorescence microscopy (Zeiss Axiovert 100 Inverted Microscope, Carl Zeiss AB) and image analysis after formaldehyde preservation and fluorescent staining of cells with acridine orange (Hobbie et al. 1977, Blackburn et al. 1998). Carbon biomass per cell was determined by a volume-dependant function according to Norland (1993) and Simon \& Azam (1989), where $m_{\mathrm{b}}$ is the bacterial carbon bio- 
mass in picograms per cell and $v_{\mathrm{b}}$ is the bacterial cell volume in cubic micrometres per cell applying the constant 0.12 as a conversion factor with the unit picograms $\mathrm{C}$ per cubic micrometre. Extended measurement uncertainty is $\pm 23 \%$. Bacterial production was measured by $1 \mathrm{~h}$ incubation at in situ temperature with ${ }^{3} \mathrm{H}$-labeled thymidine (Amersham ${ }^{\circledR}, 1 \mathrm{mCi}$ $\mathrm{ml}^{-1}, 80 \mathrm{Ci} \mathrm{mmol}^{-1}$ ), at a final concentration $25 \mathrm{nM}$ using a conversion factor of $1.4 \times 10^{18}$ cells mol$^{-1}$ (Smith \& Azam 1992, Wikner \& Hagström 1999). Triplicate incubations and 2 killed controls (5\% trichloroacetic acid final concentration) were incubated for each sample. Extended measurement uncertainty is $\pm 21 \%$.

\section{Bacterial community analysis}

Samples for PCR (polymerase chain reaction)based analyses of bacterial community composition were collected on 7 occasions during the month-long mesocosm experiment. Cells were collected by gentle vacuum filtration onto $0.2 \mu \mathrm{m}$ Supor filters (47 mm diameter, Pall). Between 0.5 and $0.7 \mathrm{l}$ from the upper mixed layer (0 to $0.2 \mathrm{~m}$ depth) was processed for each individual sample. Filters were immediately frozen at $-80^{\circ} \mathrm{C}$ until further processing. DNA was extracted using the Ultraclean Soil DNA extraction kit (MoBio Laboratories) following the protocol for maximum yield. Filters were thawed on ice before addition of ceramic beads and extraction buffer, followed by $15 \mathrm{~min}$ of vigorous shaking at $3000 \mathrm{rpm}$ using a Vortex-Genie 2 (SI Inc.). DNA was quantified by loading $4 \mu \mathrm{l}$ of the extracted nucleic acids on a $1 \%$ agarose gel stained with ethidium bromide. After $1 \%$ agarose gel electrophoresis in $0.5 \times$ TAE $\left(20 \mathrm{mM}\right.$ Tris, $10 \mathrm{mM}$ acetate, $0.5 \mathrm{mM} \mathrm{Na}_{2}$ EDTA, pH 7.2) (45 min, 120 V) genomic DNA was sized and quantified by comparison to a quantitative high molecular weight DNA mass ladder (Invitrogen). DNA concentrations ranged between 1 and

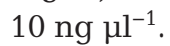

Extracted samples were PCR amplified using universal bacterial primers $27 \mathrm{f}$ (Vergin et al. 1998) and 519r (Lane et al. 1985) targeting the 16S rRNA gene. The forward primer was labeled with hexachlorofluorescein (HEX). Extracted DNA used as template was 5-fold diluted with sterile water prior to PCR amplification on a Strategene Robocycler. For each sample, 8 replicate $20 \mu \mathrm{l}$ reactions were amplified. The reaction mixtures contained $0.2 \mu \mathrm{M}$ of each primer, 2 U DNA polymerase (Finnzymes), 10× PCR buffer, $10 \mathrm{mg} \mathrm{ml}^{-1} \mathrm{BSA}, 2.5 \mathrm{mM} \mathrm{MgCl}_{2}, 10 \mathrm{mM}$
dNTPs, template DNA and sterile Q-grade water. After initial denaturation at $95^{\circ} \mathrm{C}$ for $2 \mathrm{~min}$, samples were amplified over 25 cycles at $95^{\circ} \mathrm{C}$ for $30 \mathrm{~s}, 53^{\circ} \mathrm{C}$ for $30 \mathrm{~s}$ and $72^{\circ} \mathrm{C}$ for $1 \mathrm{~min}$. A final 7 min extension was carried out at $72^{\circ} \mathrm{C}$. Replicate PCR reactions were pooled, purified and concentrated by QIAquick PCR Purification Kit (Qiagen) before quantification as described above. Bacterial community composition was assessed by terminal restriction fragment length polymorphism (T-RFLP; Osborne et al. 2006). Aliquots of $50 \mathrm{ng}$ purified PCR product were separately digested for $16 \mathrm{~h}$ at $37^{\circ} \mathrm{C}$ with the 4 -cutting restriction enzymes HinfI and HaeIII as recommended by the manufacturer (Invitrogen). Endonuclease activity was terminated by heating at $80^{\circ} \mathrm{C}$ for $20 \mathrm{~min}$. All samples were digested in duplicate on separate plates to account for any systematic differences between the runs. Terminal restriction fragments (hereafter referred to as operational taxonomic units, OTUs) were sized on an ABI 3730XL DNA sequencer (Applied Biosystems) running in Genescan mode with ROX-500 as a size standard. Electropherograms were analyzed using GeneMarker 1.7 (SoftGenetics LLCTM). Peaks between 50 and $520 \mathrm{bp}$ were analyzed with the peak detection threshold set to $0.415 \%$ of the total peak area. This cutoff was set based on procedures described by Osborne et al. (2006). The fluorescence of individual OTUs was first normalized to the total OTU fluorescence in the individual samples. The relative OTU fluorescence was subsequently square-root transformed and a Bray-Curtis similarity matrix was calculated for further comparison of bacterial community composition by non-metric multidimensional scaling (NMDS) using the Primer-6 software (Primer-E). T-RFLP samples from all 7 sampling points were analyzed for TRFLP total number of OTUs. However, to decipher treatment effects on community composition by NMDS, only samples from Day 22 onward were considered. The main reasons for excluding the earlier samples were that no addition of DOM was made to the first sampling point and that $\mathrm{BCC}$ during this early phase of the experiment largely reflects the original estuarine community and the impact of sample containment rather that the community responding to the experimental treatment.

\section{Statistical analyses}

To detect effects of time, DOM addition and stratification depth on water chemical and biological variables, including the first 2 dimensions of the 
community composition NMDS (Dim1 and Dim2), we used a test that performs a multivariate analysis of variance (MANOVA) for multiple continuous responses. In addition, we used water chemistry, primary production and $\mathrm{chl} a$ to predict bacterial production and community composition (Dim1 and Dim2). Due to the non-normal distribution of many of our variables, tested by a Shapiro-Wilk test for normality, we restricted our statistical analyses to those that are robust against non-normal distributions, i.e. non-parametric tests, or we used logtransformations. To find important drivers for bacterial production and bacterial community composition we used partial least squares regressions (PLS). PLS analyses were chosen because of the method's insensitivity to the $X$-variable's interdependency and the insensitivity to deviations from normality (Wold et al. 2001). PLS is commonly used to determine the fundamental relations between 2 matrices $(X$ and $Y$ ), where the variance in $X$ is taken to explain the variance in $Y$. In PLS, $X$-variables are ranked according to their relevance in explaining $Y$, commonly expressed as VIP-values (Wold et al. 2001). The higher the VIP-values are, the higher the contribution is of an $X$-variable to model performance. VIP-values $>1$ are considered important $X$-variables.

For the predictions of bacterial production, Dim1 and Dim2 in the 12 mesocosms, we used the following 11 variables as $X$-variables: DOC, $\mathrm{POC}$, PON, humic acids, $\mathrm{NH}_{4}, \mathrm{NO}_{3}, \mathrm{NO}_{2}$, $\mathrm{PO}_{4}, \mathrm{Si}, \mathrm{chl} a$ and primary production. Finally, we also used the non-parametric Wilcoxon test to analyze whether groups of data were significantly different $(\mathrm{p}<0.05)$. All statistical analyses were carried out in the JMP program, Version 8.

\section{RESULTS}

\section{Treatment effects on chemical and biological variables}

Using MANOVA we found significant effects of both the DOM addition and the stratification depth on most nutrients and primary production, whereas bacterial production only responded to the manipulation in stratification depth (Table 1,
Figs. 1 \& 2). There were no treatment effects on bacterial biomass. All chemical and biological variables except POC, PON and nitrate changed significantly over time, and, hence, time was the most significant factor in comparison to the other 2 factors (DOM addition and stratification depth manipulation) when tested separately (Table 1). While primary production responded to both experimental treatments, chl a as a proxy for phytoplankton biomass only had a weak response to the DOM amendment and no significant response to manipulation of stratification depth. The concentration of humic substances accumulated over time in all treatments subjected to DOM amendments, whereas the total DOC remained close to the $300 \mu \mathrm{M}$ at the start of the experiment without any significant difference in DOC concentrations among the 4 treatments (non-parametric Wilcoxon test: $\mathrm{p}>0.05$ ) (Fig. 2A,B).

Calculating the extinction coefficient, it was clear that less light was available to the organisms in mesocosms with DOM added (Treatments 1 and 3) compared to those without (non-parametric Wilcoxon test: $\mathrm{p}$ < 0.05). At the last sampling point, extinction coefficients ranged from 2.04 to 2.07 in tanks with DOM addition and 1.49 to 1.53 in tanks without such amendment with chromophoric DOM.

Table 1. Significance levels (p-values) using MANOVA. Tested were the effects of time (9 sampling occasions starting on Day 3 when DOM was added), dissolved organic matter (DOM) addition (2 treatments) and stratification depth (2 depths) on 14 different variables. All variables were logtransformed except for particulate organic carbon (POC) and particulate organic nitrogen (PON) in order to receive normal distributions. Since time mainly determined the $\mathrm{p}$-values of the overall model with the factors time, DOM additions and stratification depth as input variables, we also tested model performance without the factor time as an input variable (partial model). $\mathrm{p}<0.05$ : significant effects; ns: non-significant effects

\begin{tabular}{|lccccc|}
\hline Variable & Whole & Time & DOM & Stratification & $\begin{array}{c}\text { Part } \\
\text { model }\end{array}$ \\
& model & & & & \\
\hline DOC & $<0.0001$ & $<0.0001$ & $<0.0001$ & $\mathrm{~ns}$ & $<0.001$ \\
$\mathrm{POC}$ & $\mathrm{ns}$ & $\mathrm{ns}$ & $\mathrm{ns}$ & $\mathrm{ns}$ & $\mathrm{ns}$ \\
$\mathrm{Humic}$ substances & $<0.0001$ & $<0.0001$ & $<0.0001$ & $\mathrm{~ns}$ & $<0.0001$ \\
$\mathrm{NH}_{4}$ & $<0.0001$ & $<0.0001$ & $<0.0001$ & $\mathrm{~ns}$ & $<0.001$ \\
$\mathrm{NO}_{3}$ & $<0.0001$ & $\mathrm{~ns}$ & $\mathrm{~ns}$ & $<0.0001$ & $<0.0001$ \\
$\mathrm{NO}_{2}$ & $<0.0001$ & $<0.0001$ & $\mathrm{~ns}$ & $<0.0001$ & $<0.0001$ \\
$\mathrm{PON}$ & $\mathrm{ns}$ & $\mathrm{ns}$ & $\mathrm{ns}$ & $\mathrm{ns}$ & $\mathrm{ns}$ \\
$\mathrm{PO}_{4}$ & $<0.0001$ & $<0.0001$ & $<0.01$ & $<0.0001$ & $<0.0001$ \\
$\mathrm{Silica}$ & $<0.0001$ & $<0.0001$ & $\mathrm{~ns}$ & $<0.05$ & $\mathrm{~ns}$ \\
$\mathrm{Chl}^{2}$ & $<0.01$ & $<0.01$ & $<0.05$ & $\mathrm{~ns}$ & $\mathrm{~ns}$ \\
Primary production & $<0.0001$ & $<0.001$ & $<0.0001$ & $<0.0001$ & $<0.0001$ \\
Bacterial production & $<0.0001$ & $<0.0001$ & $\mathrm{~ns}$ & $<0.001$ & $<0.05$ \\
Bacterial biomass & $<0.0001$ & $<0.0001$ & $\mathrm{~ns}$ & $\mathrm{~ns}$ & $\mathrm{~ns}$ \\
Bacterial abundance & $<0.0001$ & $<0.0001$ & $<0.01$ & $\mathrm{~ns}$ & $<0.05$ \\
& & & & & \\
\hline
\end{tabular}



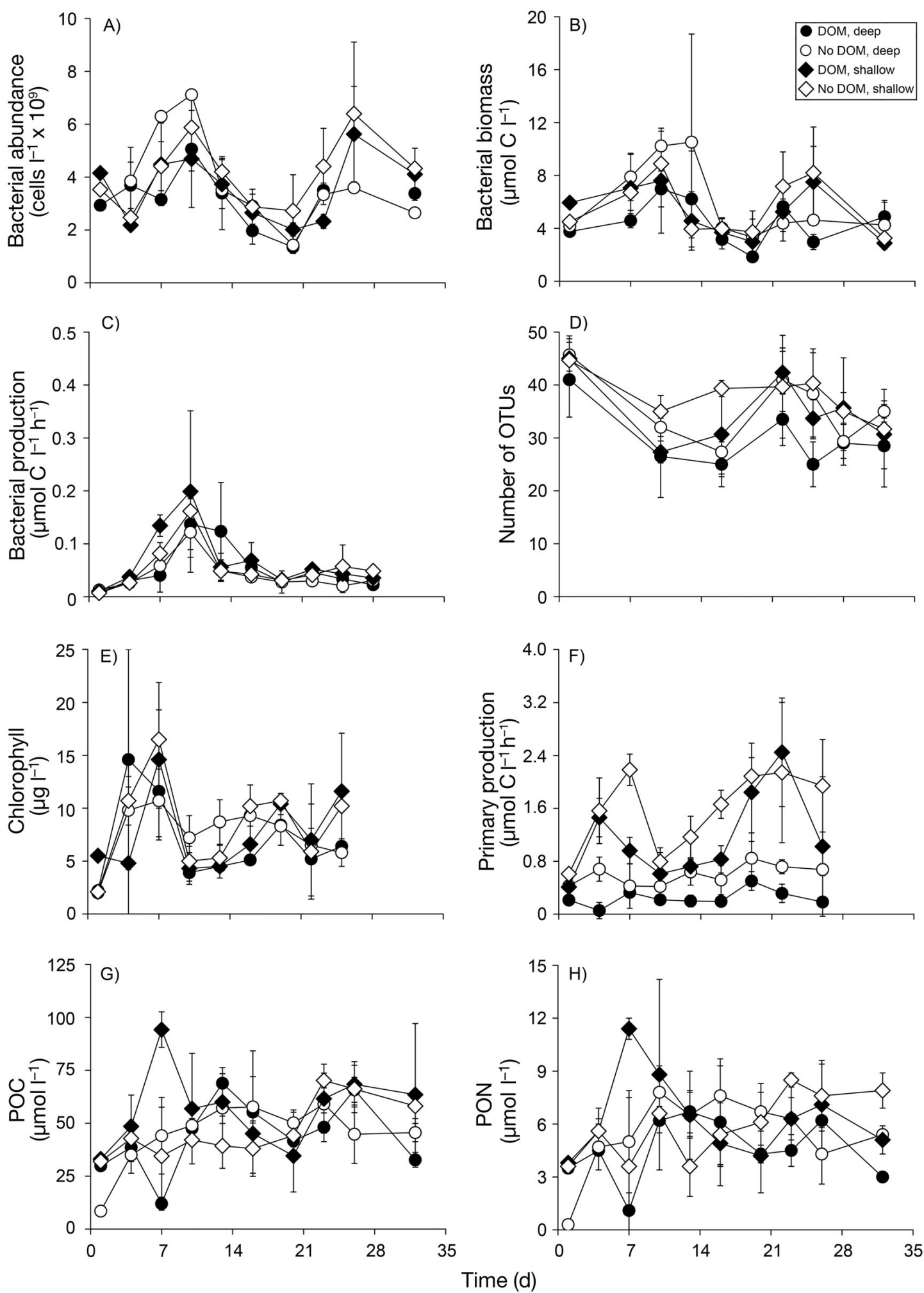

Fig. 1. Variables displayed over time for the 4 treatments. $\bullet$, mesocosms with experimentally added dissolved organic matter (DOM); O, $\diamond$ : units without addition. $\bullet$, O: stratification at $3.5 \mathrm{~m} ; \diamond$, $\diamond$ : stratification at $1.5 \mathrm{~m}$ depth (see key in Panel B). Means $\pm \mathrm{SD}, \mathrm{n}=3$ (for Treatment 1: $\mathrm{n}=2$ ). (A) Bacterial abundance, (B) bacterial biomass, (C) bacterial production, (D) terminal restriction fragments (OTUs), (E) chlorophyll $a_{1}(\mathrm{~F})$ primary production, $(\mathrm{G})$ particulate organic carbon (POC) and $(\mathrm{H})$ particulate organic nitrogen $(\mathrm{PON})$ 

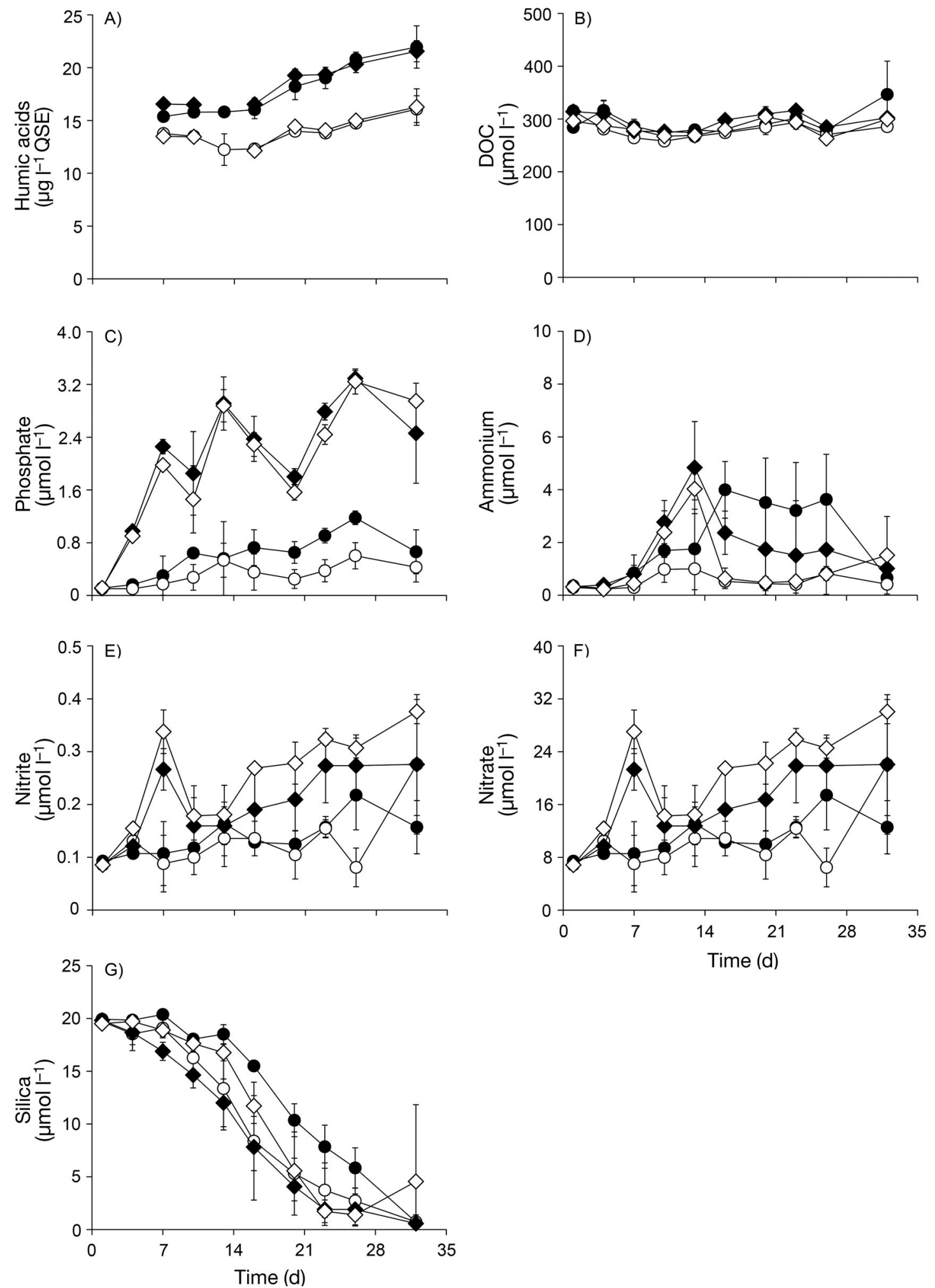

Fig. 2. Dynamic changes in dissolved nutrients over time. $\bullet \bullet:$ mesocosms with experimentally added DOM; O, $\diamond:$ units without addition. $\bullet, \mathrm{O}$ : stratification at $3.5 \mathrm{~m} ; \diamond, \diamond$ : stratification at $1.5 \mathrm{~m}$ depth. Means $\pm \mathrm{SD}, \mathrm{n}=3$. Variables displayed are $(\mathrm{A})$ humic acids, (B) dissolved organic carbon (DOC), (C) $\mathrm{PO}_{4}$, (D) $\mathrm{NH}_{4}$, (E) $\mathrm{NO}_{2}$, (F) $\mathrm{NO}_{3}$ and (G) Si. At the end of the experimental period, Si was depleted in the majority of upper mixed layers. QSE: quinine sulfate equivalents 


\section{Bacterial community composition}

Altogether 126 T-RFLP fragments (OTUs) were scored in the combined dataset. The number of unique OTUs in individual samples was highest at the start of the experiment (average 44) and then decreased to $\sim 30$ after $1 \mathrm{wk}$ to remain stable at that level for the remainder of the experiment (Fig. 1D). Comparing OTU profiles at the start and end of the month-long experiment, only 5 OTUs were present in all samples across the 4 treatments.

Addition of DOM had a strong effect on bacterial community composition, with larger differences relative to the unamended controls at the end of the experiment (Fig. 3). Also the manipulation of stratification depth influenced bacterial community composition (Fig. 3). A pairwise comparison of binary (presence/absence) TRFLP data for any combination of bacterial community composition samples displayed in Fig. 3 revealed that, on average, $71 \%$ of the OTUs were shared between any 2 samples (range: 55 to $90 \%$ ). Using PLS models for the prediction of bacterial production and bacterial community composition with 11 chemical and biological input variables, we could explain $33 \%$ of the variance in bacterial production and $85 \%$ of the bacterial community composition (Dim 1) (Table 2). A wide range of water chemistry variables (nutrient levels as well as humic

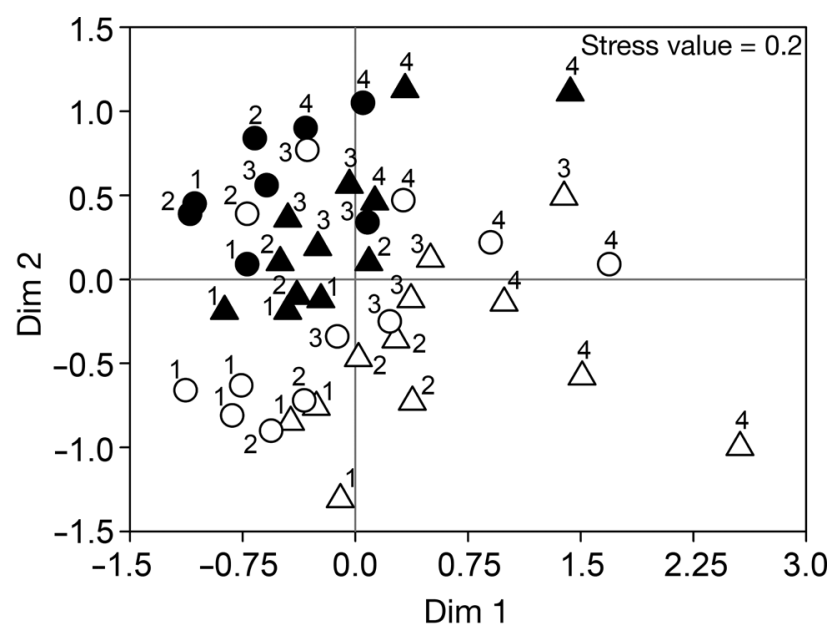

Fig. 3. The first 2 dimensions (Dim1 and Dim2) of the community composition NMDS (non-metric multidimensional scaling) based on Bray-Curtis similarity of community fingerprint patterns (OTUs) over the last 4 sampling dates. Numbers display the community for each replicate $(1=$ Day 22; 2 = Day 25; 3 = Day 28; 4 = Day 32)., $\mathbf{\Delta}$ : mesocosms with experimentally added $\mathrm{DOM}_{i} \mathrm{O}, \Delta$ : units without addition. $\bullet$, stratification at $3.5 \mathrm{~m} ; \boldsymbol{\Delta}, \Delta$ : stratification at $1.5 \mathrm{~m}$ depth
Table 2. Importance of chemical and biological variables for the prediction of bacterial production (BP) and bacterial community composition (Dim1 and Dim2) in all 11 mesocosms using partial least square regressions for Days 22 to 32. Given are VIP values (see 'Materials and methods: Statistical analyses' for definition). The higher the VIP values are, the more important the $X$-variable is for model performance. VIP $>1.0$ (in bold) are considered important input variables. The $X$-variables explained $33 \%$ of $\mathrm{BP}, 85 \%$ of Dim1 and $70 \%$ of Dim2

\begin{tabular}{|lccc|}
\hline \multirow{2}{*}{$X$-variable } & \multicolumn{3}{c|}{ Prediction } \\
\cline { 2 - 4 } & BP & Dim1 & Dim2 \\
\hline Dissolved organic carbon & 0.48 & $\mathbf{1 . 4 1}$ & $\mathbf{1 . 2 6}$ \\
Particulate organic carbon & 0.86 & $\mathbf{1 . 0 4}$ & 0.29 \\
Humic acids & $\mathbf{1 . 1 6}$ & $\mathbf{1 . 3 5}$ & $\mathbf{2 . 0 2}$ \\
$\mathrm{NH}_{4}$ & 0.92 & $\mathbf{1 . 6 0}$ & $\mathbf{1 . 7 6}$ \\
$\mathrm{NO}_{3}$ & $\mathbf{1 . 3 7}$ & $\mathbf{1 . 1 1}$ & 0.55 \\
$\mathrm{NO}_{2}$ & $\mathbf{1 . 4 4}$ & 0.95 & 0.43 \\
$\mathrm{Particulate} \mathrm{organic} \mathrm{nitrogen}$ & 0.88 & $\mathbf{1 . 0 9}$ & $\mathbf{1 . 2 1}$ \\
$\mathrm{PO}_{4}$ & $\mathbf{1 . 7 9}$ & $\mathbf{1 . 2 5}$ & $\mathbf{1 . 0 4}$ \\
Silica & 0.76 & $\mathbf{1 . 4 3}$ & 0.70 \\
$\mathrm{Chl} a$ & 0.94 & $\mathbf{1 . 0 0}$ & 0.28 \\
Primary production & 0.96 & 0.88 & $\mathbf{1 . 1 5}$ \\
\hline
\end{tabular}

acids) were important predictors of bacterial production and bacterial community composition. Biological variables such as primary production and phytoplankton biomass (chl a) were less significant in this regard (Table 2).

\section{DISCUSSION}

Heterotrophic bacterioplankton play central roles in most biogeochemical cycles, and their metabolic use of DOM represents a critical energy and nutrient subsidy for aquatic food webs (Sandberg et al. 2004). This ability to exploit aquatic DOM for growth and other functional traits is partially controlled by BCC (Bertilsson et al. 2007). In the present study we assessed how this community feature responded to enhanced inputs of DOM and manipulated stratification depth linked to altered effective light climate. Bacterial community fingerprints based on T-RFLP of the 16S rRNA gene showed that the composition of these communities responded significantly to both of these manipulations (Fig. 3). With this method, less abundant taxa will be overlooked, but these rare populations will most likely not be quantitatively significant in broader ecosystem-scale processes such as microbial-mediated degradation of DOM. It can therefore be argued that this method captures the functionally most relevant populations within a community (Bertilsson et al. 2007). 
When tracing bacterial community composition over time, there was a distinct divergence of communities in response to the variable DOM amendments that was not evident in the manipulation of stratification depth (Fig. 3). This may reflect an additive effect of the sequential DOM additions with gradually changing DOM quality, while DOC concentration remained stable (Fig. 2A,B). Such gradual depletion in the more labile portions of the total DOM pool and a concomitant enrichment in more recalcitrant humic substances have been observed previously (HutalleSchmelzer et al. 2010). It has also been shown that DOM quality can have a strong effect on bacterial community composition, not least considering the relative supply of humic or phytoplankton-derived organic compounds and the concentration of dissolved organic nitrogen (Kisand et al. 2002, Sandberg et al. 2004, Hutalle-Schmelzer et al. 2010). The gradual changes in T-RFLP patterns observed in the present study might thus reflect a substrate-induced increase in initially rare bacterial populations adapted to grow efficiently on the more labile portions of DOM added, to later be replaced by populations specialized in metabolizing the more recalcitrant but also gradually more abundant humic substances. These emerging populations would then increase in relative abundances to levels that can be detected with our community fingerprinting method, whereas other, less successful competitors would fall below the detection limit.

Stratification of the water column influenced both the distribution of nutrients and the effective light climate experienced by phytoplankton as well as pelagic bacteria in this upper mixed layer. This manipulation also caused a change in bacterial community composition (Fig. 3). Phytoplankton primary production responded significantly to this treatment, whereas chl a was unaffected, suggesting a coupled change also in the concentration of phytoplanktonderived DOM potentially made available to the heterotrophic community (Bertilsson \& Jones 2003). The elevated primary production at shallow stratification depth could both be a result from higher nutrient levels (Fig. 2) or enhanced availability of light, or a combination thereof. The observed differences in primary production are not unexpected, as incubations to assess primary production were carried out at variable depths to directly account for the differences in average effective light climate experienced by phytoplankton in mesocosms with shallow and deep stratification depths, respectively. These effects of variable stratification depth are similar to the findings of Lydersen et al. (2008), although their study did not target bacteria. In the latter study, manipulation of the thermocline in Lake Breisjøen resulted in few and small changes in biota. For example, phytoplankton biomass and productivity did not change, whereas a shift in phytoplankton species richness and composition was observed.

Mesocosm incubations can be a useful complement to microscale and ecosystem-level experiments as it captures some of the structural and spatial complexity in natural ecosystems while enabling replication and controls for certain experimental manipulations (e.g. DOC and stratification depth). In natural ecosystems, such replicated large-scale manipulations would probably take many years to complete if they are at all possible (Spivak et al. 2011). Still, mesocosms cannot perfectly mimic natural ecosystems, and, in the current study, there was, for example, minimal UV-exposure of the water. In solar-exposed surface waters, this high-energy radiation may influence the bioavailability of DOM and also directly inhibit biological processes (Tranvik \& Bertilsson 2001), with a coupled influence on bacterial community composition. Mesocosm facilities, particularly indoor facilities such as the ones used in the current experiment, are furthermore largely protected from the action of winds and waves that drive circulation of the upper surface layer in natural water bodies. Although the water above the thermocline in the mesocosms studied here was circulated with continuous bubbling, mixing characteristics and crossboundary transport of organisms, particles, gases and dissolved constituents may differ from the natural environment and fluxes should thus be interpreted with caution.

Even though the number of T-RFLP peaks was similar among treatments in our mesocosm study, there were significant differences in the identity of the specific OTUs detected (Fig. 3). During the initial phase of the experiment, many OTUs were lost, indicating an environmental change that was not conducive for all estuarine bacteria originally present in the mesocosms (Fig. 1D). One major initial impact that could have had a dramatic effect on the composition of the bacterial community was the raise in temperature introduced in the experimental mesocosms. Temperature has previously been pointed out as a major structuring factor for bacterial communities in the studied estuarine waters (Hoikkala et al. 2009) and could, in combination with a general containment disturbance, explain the initial drop in the number of OTUs and the temporary increase in bacterial biomass and production observed during the first $2 \mathrm{wk}$ of the experiment (Fig. 2B,C). Besides affecting 
bacterial community composition, sudden shifts in temperature will likely also accelerate the overall rate of metabolic processes, including nutrient turnover and DOM degradation (Pinhassi et al. 2006). This effect would, however, apply equally to all treatments and would also influence primary producers and grazers. Nevertheless, both absolute rates and organism abundances should be interpreted with some caution.

In mesocosms subjected to DOM amendment, the concentration of chromophoric humic acids started to accumulate, whereas DOC concentrations remained constant (Fig. 2). This implies qualitative changes in the combined DOM pool where the proportion of humic acids increases gradually over time. Besides the direct change in the DOM pool potentially available for heterotrophic growth, this 'humification' will also restrict light penetration and the effective light climate for the remainder of the planktonic food web. These qualitative changes and the absence of any measurable net accumulation of DOM, despite the combined addition of $0.24 \mathrm{mmol} \mathrm{C} \mathrm{l}^{-1}$ to the DOMamended mesocosms, could suggest that heterotrophic degradation of organic matter is higher in the DOM-amended mesocosms, with a gradual accumulation of the most recalcitrant (humic) portion of the DOM (Hoikkala et al. 2009). However, this was not reflected in enhanced bacterial production or biomass in the DOM-amended mesocosms, implying that if microbial processing of DOM was indeed higher in these treatments, then bacterial growth efficiency, the proportion of metabolized carbon allocated to production of new biomass, must have been substantially lower compared to the unamended reactors. This is less likely since $0.05 \mathrm{mmol} \mathrm{l}^{-1}$ of the external carbon added to the DOM-amended mesocosms was represented by biologically labile and protein-rich organic substrates, typically used at high growth efficiencies (Bertilsson et al. 2007). In comparison, the average bacterial production over the total experimental period ranged from 0.04 to $0.078 \mu \mathrm{mol} C$ $\mathrm{l}^{-1} \mathrm{~h}^{-1}$ in the 4 treatments (Fig. 1C). Applying these average production rates to the month-long duration of the experiment, this corresponds to a cumulative bacterial biomass production ranging from $0.03 \mathrm{mmol}$ $\mathrm{C}^{-1}$ in the shallow mesocosms without DOM added to $0.05 \mathrm{mmol} \mathrm{C} \mathrm{^{-1 }}$ in the deep mesocosms amended with DOM. Hence, the measured bacterial production was similar to the amount of yeast extract carbon added, and, assuming a realistic bacterial growth efficiency of $50 \%$ for these protein-rich substrates (Bertilsson et al. 2007), the yeast extract alone could account for up to half of the bacterial carbon demand in the DOM-amended mesocosms, most likely also with coupled effects on BCC. Such a strong influence of labile organic substrates (glucose) on BCC has previously been observed in mesocosm experiments (Töpper et al. 2010).

An alternative, but non-exclusive, explanation for the constant DOC levels over time could be a loss from the surface water as a result of enhanced aggregation and sedimentation due to chemical as well as biological transformation processes (von Wachenfeldt et al. 2009 and references therein). Either way, such accelerated carbon burial did not cause an increase in either bacterial biomass or production in the surface water, implying that the added organic carbon was not transferred to higher trophic levels, but lost from these waters either as $\mathrm{CO}_{2}$ or via enhanced sedimentation to deeper strata. One indication that such sedimentation processes might be significant in the present experiment is the gradual depletion of silica from the upper mixed layer, likely because of sedimentation losses of dead or inactive diatoms. Overall, diatoms were, by far, the dominant phytoplankton group in the mesocosm experiment, and sedimentation of such biomass would also deplete the surface water of organic carbon, nitrogen and phosphorus.

The concentration of several inorganic nutrients also changed in response to the treatments (Fig. 2). In mesocosms with a shallow upper mixed layer, phosphate, nitrate and nitrite were significantly higher compared to in mesocosms with a deeper pycnocline. One can only speculate about the specific mechanisms that led to this apparently more efficient retention of nutrients in the upper mixed layer, but the increase in primary production paralleled by equal chl a levels in mesocosms with deep and shallow pycnoclines might indicate a more rapid turnover of these primary producers and a grazing-induced remineralisation of nutrients from biomass. In contrast, ammonium levels did not respond to this experimental treatment, but instead changed in response to DOM manipulation. The enhanced ammonium concentrations in both deep and shallow mesocosms receiving a combination of humic and more labile organic matter is most likely derived from mineralization of the added DOM, and particularly the protein- and, hence, nitrogen-rich yeast extract. Such indirect treatment effects, leading to variable levels of inorganic phosphate and nitrogen species, could also have a strong effect on BCC (Teira et al. 2010), which is also suggested by the PLS model where the concentrations of several nutrients were strong predictors of BCC (Table 2). 
In a situation where nutrients become potentially limiting, bacteria or small phytoplankton are believed to have a competitive advantage relative to larger phytoplankton as a result of their small surface to volume ratio (Thingstad 1998). Such structuring forces may also shift the phytoplankton community composition and its susceptibility to herbivory and thus modify carbon flow in the food web. Since the mesocosm consisted of natural water taken from the Gulf of Bothnia, it is reasonable to expect that some of the observed results may be due to secondary effects and trophic cascades, especially since zooplankton were not removed. This would also influence bacterivory via removal of heterotrophic nanoflagellates and other small bacterivores with changes in the bacterial community composition according to predation resistance (Pernthaler \& Amann 2005).

In summary, bacterial community compositions in these estuarine mesocosms were influenced both by stratification depth and experimental DOM amendment, where the quality of DOM and nutrient availability coupled to phytoplankton growth appeared to play central roles in structuring the predominantly heterotrophic bacterial community.

Acknowledgements. We thank Jürg Brendan Logue for sharing his knowledge about T-RFLP. We thank the staff at Umeå Marine Research Sciences Centre for their help with sampling and analysis, as well as the participants of the Nordic Marine Academy course for help with sampling. Constructive comments from 4 anonymous reviewers substantially improved the manuscript. This study was funded by the Swedish Research Council Formas (grant to S.B.) and the Kempe foundation (SMK-2458, grant to J.W.). Access to the newly constructed mesocosm facility at Umeå Marine Sciences Centre was made possible by a grant from the Nordic Marine Academy to U.B.

\section{LITERATURE CITED}

Aminot A, Rey F (2002) Chlorophyll a: determination by spectroscopic methods. ICES Tech Mar Environ Sci 30: $1-18$

Bergström A, Jansson M (2000) Bacterioplankton production in humic Lake Örträsket in relation to input of bacterial cells and input of allochthonous organic carbon. Microb Ecol 39:101-115

Bertilsson S, Jones BR Jr (2003) Supply of dissolved organic matter to aquatic ecosystems: autochthonous sources. In: Findlay SEG, Sinsabaugh RL (eds) Aquatic ecosystems interactivity of dissolved organic matter. Academic Press, San Diego, CA, p 3-24

Bertilsson S, Eiler A, Nordqvist A, Jørgensen NOG (2007) Links between bacterial production, amino-acid utilization and community composition in productive lakes. ISME J 1:532-544

Blackburn N, Hagström Å, Wikner J, Cuadros Hansson R,
Bjørnsen P (1998) Rapid determination of bacterial abundance, biovolume, morphology, and growth by neural network-based image analysis. Appl Environ Microbiol 64:3246-3255

> Coble PG, Green SA, Blough NV, Gagosian RB (1990) Characterization of dissolved organic matter in the Black Sea by fluorescence spectroscopy. Nature 348:432-435

Colijn F, Edler L (1998) Working manual on the use of a standardized incubator technique in primary production measurements. In: Report of the ICES WG on phytoplankton ecology. ICES CM 1998/C:3

Eiler A, Langenheder S, Bertilsson S, Tranvik LJ (2003) Heterotrophic bacterial growth efficiency and community structure at different natural organic carbon concentrations. Appl Environ Microbiol 69:3701-3709

Grasshoff K, Ehrhardt E, Kremling K (1983) Methods of seawater analysis. Verlag Chemie, Weinheim

Haukka K, Heikkinen E, Kairesalo T, Karjalainen H, Sivonen K (2005) Effect of humic material on the bacterioplankton community composition in boreal lakes and mesocosms. Environ Microbiol 7:620-630

HELCOM (2003) Manual for marine monitoring in the COMBINE programme of HELCOM, Part C. Programme for monitoring of eutrophication and its effects. Available at: www.helcom.fi/groups/monas/CombineManual/Part C/en_GB/main/

Hobbie JE, Daley RJ, Jasper S (1977) Use of Nuclepore filters for counting bacteria by fluorescence microscopy. Appl Environ Microbiol 1977:1225-1228

> Hoikkala L, Aarnos H, Lignell R (2009) Changes in nutrient and carbon availability and temperature as factors controlling bacterial growth in the northern Baltic Sea. Estuar Coasts 32:720-733

Hutalle-Schmelzer KML, Zwirnmann E, Krüger A, Grossart HP (2010) Enrichment and cultivation of pelagic bacteria from a humic lake using phenol and humic matter additions. FEMS Microbiol Ecol 72:58-73

Jones RJ (1998) Phytoplankton, primary production and nutrient cycling. In: Hessen DO, Tranvik LJ (eds) Aquatic humic substances, ecology and biogeochemistry. Ecological Studies 133, Springer-Verlag, Berlin, p 145-175

> Kisand V, Cuadros R, Wikner J (2002) Phylogeny of culturable estuarine bacteria catabolizing riverine organic matter in the northern Baltic Sea. Appl Environ Microbiol 68:379-388

> Kisand V, Rocker D, Simon M (2008) Significant decomposition of riverine humic-rich DOC by marine but not estuarine bacteria assessed in sequential chemostat experiments. Aquat Microb Ecol 53:151-160

> Kritzberg ES, Langenheder S, Lindström ES (2006) Influence of dissolved organic matter source on lake bacterioplankton structure and function-implications for seasonal dynamics of community composition. FEMS Microbiol Ecol 56:406-417

Kuparinen J, Leonardsson K, Mattila J, Wikner J (1996) Food web structure and function in the Gulf of Bothnia, the Baltic Sea. Ambio (Spec Issue) 8:13-21

> Lane DJ, Pace B, Olsen GJ, Stahl DA, Sogin ML, Pace NR (1985) Rapid determination of $16 \mathrm{~S}$ ribosomal RNA sequence for phylogenetic analyses. Proc Natl Acad Sci USA 82:6955-6959

Lydersen E, Aanes KJ, Andersen S, Andersen T and others (2008) Ecosystem effects of thermal manipulation of a whole lake, Lake Breisjøen, southern Norway (THERMOS project). Hydrol Earth Syst Sci 12:509-522 
Norland S (1993) The relationship between biomass and volume of bacteria. In: Handbook of methods in aquatic microbial ecology. Kemp PF (ed) Lewis Publishers, Boca Raton, FL, p 303-307

Osborne CA, Rees GN, Bernstein Y, Janssen PH (2006) New threshold and confidence estimates for terminal restriction fragment length polymorphism analysis of complex bacterial communities. Appl Environ Microbiol 72:1270-1278

Pernthaler J, Amann R (2005) Fate of heterotrophic microbes in pelagic habitats-Focus on populations. Microbiol Mol Biol Rev 69:440-461

Pettersson C, Allard B, Borén H (1997) River discharge of humic substances and humic-bound metals to the Gulf of Bothnia. Estuar Coast Shelf Sci 44:533-541

Pinhassi J, Gómez-Consarnau L, Alonso-Sáez L, Sala MM, Vidal M, Pedrós-Alió C, Gasol JM (2006) Seasonal changes in bacterioplankton nutrient limitation and their effects on bacterial community composition in the NW Mediterranean Sea. Aquat Microb Ecol 44:241-252

Räisänen J, Hansson U, Ullerstig A, Doscher R and others (2004) European climate in the late twenty-first century: regional simulations with two driving global models and two forcing scenarios. Clim Dyn 22:13-31

Sandberg J, Andersson A, Johansson S, Wikner J (2004) Pelagic food web structure and carbon budget in the northern Baltic Sea: potential importance of terrigenous carbon. Mar Ecol Prog Ser 268:13-29

Simon M, Azam F (1989) Protein content and protein synthesis rates of planktonic marine bacteria. Mar Ecol Prog Ser 51:201-213

Smith DC, Azam F (1992) A simple, economical method for measuring bacterial protein synthesis rates in seawater using ${ }^{3} \mathrm{H}$-leucine. Mar Microb Food Webs 6:107-114

Søndergaard M, Middelboe M (1995) A cross-system analysis of labile dissolved organic carbon. Mar Ecol Prog Ser 118:283-294

Spivak AC, Vanni MJ, Mette EM (2011) Moving on up: Can results from simple aquatic mesocosm experiments be applied across broad spatial scales? Freshw Biol 56: 279-291

Editorial responsibility: Matthias Seaman, Oldendorf/Luhe, Germany
Stepanauskas R, Moran MA, Bergamasch BA, Hollibaugh JT (2003) Covariance of bacterioplankton composition and environmental variables in a temperate delta system. Aquat Microb Ecol 31:85-98

- Teira E, Martinez-García S, Calvo-Díaz A, Móran XAG (2010) Effects of inorganic and organic nutrient inputs on bacterioplankton community composition along a latitudinal transect in the Atlantic Ocean. Aquat Microb Ecol 60:299-313

> Thingstad TF (1998) A theoretical approach to structuring mechanisms in the pelagic food web. Hydrobiologia 363: $59-72$

Tranvik L, Bertilsson S (2001) Contrasting effects of solar UV radiation on dissolved organic sources for bacterial growth. Ecol Lett 4:458-463

Töpper B, Larsen A, Thingstad TF, Thyrhaug R, Sandaa RA (2010) Bacterial community composition in an Arctic phytoplankton mesocosm bloom: the impact of silicate and glucose. Polar Biol 33:1557-1565

> Vergin KL, Urbach E, Stein JL, DeLong EF, Lanoil BD, Giovannoni SJ (1998) Screening a fosmid library of marine environmental genomic DNA fragments reveals four clones related to members of the order Planctomycetales. Appl Environ Microbiol 64:3075-3078

> von Wachenfeldt E, Bastviken D, Tranvik LJ (2009) Microbially induced flocculation of allochthonous dissolved organic carbon in lakes. Limnol Oceanogr 54: 1811-1818

Wedborg M, Skoog A, Fogelqvist E (1994) Organic carbon and humic substances in the Baltic Sea, the Kattegat and the Skagerrak. In: Senesi N, Miano TM (eds) Humic substances in the global environment and implications on human health. Elsevier, Amsterdam p 917-924

Wikner J, Hagström ^ (1999) Bacterioplankton intra-annual variability at various allochthonous loading: importance of hydrography and competition. Aquat Microb Ecol 20: 245-260

> Wold S, Sjöström M, Eriksson L (2001) PLS-regression: a basic tool of chemometrics. Chemom Intell Lab Syst 58: 109-130

Submitted: April 4, 2011; Accepted: January 26, 2012 Proofs received from author(s): April 19, 2012 